\title{
Bajo mi real protección y amparo: os decretos espanhóis de liberdade a escravos fugitivos e os conflitos imperiais no Atlântico, 1680-1791
}

Gabriel Aladrén*

Universidade Federal Fluminense, Niterói, Rio de Janeiro, Brasil

\section{RESUMO}

Neste artigo, examinarei os decretos emitidos pelos reis espanhóis e autoridades hispano-americanas para libertar escravos fugidos de colônias estrangeiras. O objetivo é interpretar esse conjunto de leis - composto por cédulas, provisōes, ordens e instruçôes registradas desde 1680 até o fim do século XVIII - no campo da política internacional e da rivalidade interimperial. Argumento que, a despeito dos precedentes na tradiçáo normativa castelhana, que remontam à época medieval, esse conjunto de dispositivos legais constituía, antes de tudo, um recurso diplomático empregado pela Coroa espanhola em suas relaçóes com Estados europeus que possuíam impérios escravistas no Atlântico.

Palavras-chave: escravidão; escravos fugitivos; império espanhol; relações internacionais; direito indiano.

\section{RESUMEN}

En este artículo examinaré los decretos promulgados por los reyes de Espańa y autoridades hispanoamericanas que liberaban esclavos fugitivos de colonias extranjeras. El reto es interpretar ese conjunto de leyes, compuesto por cédulas, provisiones, órdenes e instrucciones publicadas desde 1680 hasta finales del siglo XVIII, en el ámbito de la política internacional y de las rivalidades imperiales. Mi argumento es que, a pesar de los precedentes en la tradición jurídica castellana que se remontan a la Edad Media, esa legislación era utilizada, antes que todo, como recurso diplomático de la Corona española en sus relaciones con los demás Estados europeos que poseían imperios esclavistas en el Atlántico.

Palabras claves: esclavitud; esclavos fugitivos; imperio español; relaciones internacionales; Derecho indiano.

DOI - http://dx.doi.org/10.1590/2237-101X01803604

Artigo recebido em 19 de outubro de 2016 e aprovado para a publicação em 15 de julho de 2017.

* Pesquisador da Universidade Federal Fluminense. E-mail: gabrielaladren@yahoo.com.br. A pesquisa e a redação deste artigo foram financiadas por bolsas de pós-doutorado do CNPq e da FAPESP. Agradeço as valiosas sugestóes de Rafael Marquese e dos colegas do grupo de pesquisa Lab-Mundi (USP), que discutiram uma primeira versão do texto. 


\section{ABSTRACT}

This paper examines the decrees issued by the Spanish kings and colonial authorities granting freedom to runaway slaves from foreign colonies. The aim is to interpret these laws, comprised of royal cedulas, proclamations, orders, and instructions, which have been registered from 1680 to the late eighteenth century, in the field of international politics and inter-imperial rivalry. I claim that, despite the precedents in Castilian legal tradition dating back to medieval times, this set of legal dispositions was, above all, a diplomatic expedient used by the Spanish Crown as a threat to rival slavery-based Atlantic empires.

Keywords: slavery; fugitive slaves; international relations; Spanish empire; Law of the Indies.

A escravidáo e o tráfico de escravos constituem matéria da diplomacia e do direito internacional desde o século XVI. Por um lado, a escravidão, enquanto forma de dominação extrema que destitui o poder e o status de uma pessoa, reduzindo-a à morte social, naturalmente tornou-se objeto da preocupação de juristas, teólogos e filósofos, e do esforço normativo de entidades políticas. Por outro, a escravidão moderna, enquanto relaçáo de produção, foi desde o princípio um empreendimento de natureza internacional: os processos de escravização e tráfico só eram possíveis em virtude da cooperação, forçada ou voluntária, entre diversos Estados e unidades políticas, que estabeleciam complexos mercantis de grande escala envolvendo agentes de diferentes naçôes e pertencimentos político-culturais. ${ }^{1}$

Ainda que regulada no interior dos Estados e sujeita, no mundo ibérico, ao poder doméstico, a escravidão sempre interferiu no campo das relaçôes interestatais. Na Idade Moderna, o tráfico negreiro foi um instrumento decisivo da política colonial dos impérios europeus. Na virada do século XVIII, o surgimento dos movimentos antiescravistas, a promulgação de constituiçôes com definição de direitos de cidadania e a ascensão da Grã-Bretanha à condição de potência hegemônica tornaram as disputas em torno da legalidade da escravidão e do tráfico um tema crucial para a ordem internacional oitocentista. As lutas dos escravos, as revoluçóes atlânticas e o abolicionismo deixaram um legado importante para a noçáo de direitos humanos, a qual por sua vez embasa as iniciativas de cooperaçáo internacional para supressão da escravidão contemporânea, uma realidade que persiste a despeito de sua ilega-

\footnotetext{
${ }^{1}$ A definição de escravidão como morte social foi elaborada por PATTERSON, Orlando. Slavery and social death: a comparative study. Cambridge, MA: Harvard University Press, 1982 p. 1-76. Uma análise sobre a escravidão moderna e sua legitimidade jurídica e religiosa pode ser encontrada em DAVIS, David Brion. $O$ problema da escravidão na cultura ocidental. Rio de Janeiro: Civilização Brasileira, 2001, p. 113-224. A obra clássica que concebe a escravidão e o tráfico negreiro como empreendimentos da moderna economia mundial é WILLIAMS, Eric. Capitalism and slavery. Chapel Hill, NC: The University of North Carolina Press, 1944.
} 
lidade em todos os quadrantes do globo. ${ }^{2}$

No período histórico aqui observado, a escravidão e o tráfico transatlântico eram temas centrais do direito e da diplomacia, tanto por integrarem os debates jurídicos sobre o direito natural e o das gentes como por se situarem no âmago dos conflitos em torno da regulação interestatal do comércio atlântico. A relação entre direito, política internacional e escravidáo é marcante na tradição jurídica espanhola, sobretudo no regime jurídico hispano-americano. O direito indiano foi composto a partir do repertório legal castelhano, adaptado e transformado por normas emitidas na Península e na América. ${ }^{3}$

As leis que libertavam escravos fugidos de colônias estrangeiras são um exemplo de normativa baseada na tradiçáo castelhana e inovada pela experiência no Novo Mundo. Trata-se de uma série de decretos, comumente exarados na forma de reais cédulas, emitidos entre 1680 e 1789. Seguindo Eugenio Petit Muñoz, utilizarei a expressão "direito de asilo" para designar esse conjunto de leis. ${ }^{4}$ Tendo em vista sua reiteração ao longo de um século, é possível afirmar que tal corpo legal constituía uma política da Coroa espanhola, empregada como recurso nas negociaçôes diplomáticas e meio de pressão sobre potências europeias rivais que sustentavam seus impérios coloniais no escravismo.

Neste artigo, analisarei esses decretos no campo da diplomacia e da rivalidade entre os impérios atlânticos. $\mathrm{O}$ rastreamento das fontes do direito, seja a jurisprudência, os códigos legais ou as práticas costumeiras é importante para a discussão da política do asilo, mas não será esta a perspectiva adotada. ${ }^{5}$ Minha interpretação, ao contrário, empurra para o segundo

\footnotetext{
${ }^{2}$ Sobre o tráfico de escravos como instrumento da política colonial dos impérios europeus cf. ALENCASTRO, Luiz Felipe de. O trato dos viventes: formação do Brasil no Atlântico Sul. São Paulo: Companhia das Letras, 2000. O legado das lutas antiescravistas para a concepção moral e jurídica de direitos humanos foi examinado por HUNT, Lynn. A invençâo dos direitos humanos: uma história. São Paulo: Companhia das Letras, 2009, p. 160-168 e BLACKBURN, Robin. The American crucible: slavery, emancipation and human rights. Londres: Verso, 2011. Sobre a definição jurídica da escravidão, histórica e contemporânea, e seu impacto no direito internacional cf. ALLAIN, Jean (Org.). The legal understanding of slavery. Oxford: Oxford University Press, 2012.

3 TAU ANZOÁTEGUI, Víctor. Nuevos horizontes en el estudio histórico del derecho indiano. Buenos Aires: Instituto de Investigaciones de Historia del Derecho, 1997.

${ }^{4}$ Petit Muñoz adotou a expressão "derecho de asilo" para nomear as leis espanholas que determinavam a alforria dos escravos fugidos de colônias estrangeiras: PETIT MUÑOZ, Eugenio et al. La condición jurídica, social, económica y politica de los negros durante el coloniaje en la Banda Oriental. Montevidéu: Facultad de Derecho y Ciencias Sociales, 1948, p. 241-249. O autor as reputa parte integrante de uma tradição jurídica espanhola, iniciada com as Siete Partidas, que teria tido um impacto no florescimento de doutrinas antiescravistas no império espanhol. Petit Muńoz interpretava as leis de "direito de asilo" como etapas de um processo que acabaria por extinguir a escravidáo no Rio da Prata. Juristas portugueses, em meados do século XIX, já haviam realizado operação semelhante, ao descontextualizarem as leis pombalinas de 1761 e 1773 . Cf. SILVA, Cristina Nogueira da e GRINBERG, Keila. Soil free from slaves: slave law in the late eighteenth- and early nineteenth century Portugal. Slavery \& Abolition, v. 32, n. 3, p. 431-446, 2011.

${ }^{5}$ Alguns trabalhos discutiram o tema, com abordagens variadas: TEPASKE, John J. The fugitive slave: intercolonial rivalry and Spanish slave policy, 1687-1764. In: PROCTOR, Samuel (Org.). Eighteenth-century Florida and its borderlands. Gainesville: University of Florida Press, 1975, p. 1-12; LANDERS, Jane. Spanish sanctuary: fugitives in Florida, 1687-1790. The Florida Historical Quarterly, v. 62, n. 3, p. 296-313, 1984;
} 
plano as justificativas filosóficas e o enraizamento legal das reais cédulas, e coloca em evidência a política internacional, as guerras e a diplomacia. Contudo, isso não significa afirmar que não havia relação entre o asilo como política e instrumento diplomático e como norma legal. Keila Grinberg argumenta com propriedade que os decretos dos reis espanhóis criaram jurisprudência no direito internacional e foram frequentemente utilizados, no século XIX, para elaboração de tratados de extradição e resolução de disputas em torno da liberdade de escravos que cruzavam as fronteiras dos Estados nacionais. ${ }^{6}$

\section{O direito de asilo no Novo Mundo: precedentes normativos e a liberdade dos índios}

Petit Muñoz alega que as leis de libertação de escravos fugidos de colônias estrangeiras eram uma prolongação, para o Novo Mundo, de um princípio arraigado na tradição jurídica de Castela, o direito de asilo territorial. Este distinguia-se do eclesiástico, o qual se limitava ao recinto de templos e lugares sagrados e, desde as Siete Partidas de Alfonso $\mathrm{X}$, amparava criminosos e escravos, mas excluía os servos. O territorial, por sua vez, nasceu em Roma e recebeu impulso em três momentos: primeiro, com o asilo municipal, na época medieval, que libertava servos recebidos no território dos conselhos; segundo, com o amparo a escravos de domínios muçulmanos que fugiam para terras da Cristandade, prática frequente na Reconquista e positivada nas Partidas; terceiro, o asilo consagrado pelo direito indiano para libertação de índios escravos provenientes de colônias limítrofes aos domínios espanhóis. ${ }^{7}$

O direito indiano é uma das chaves para compreender a emergência do asilo para escravos negros, pois este foi regulado à luz da normativa sobre os meios legítimos para escravização de indígenas. ${ }^{8}$ Desde meados do século XVI uma série de disposiçôes sobre a liberdade dos índios foi enunciada, especialmente no contexto da promulgação das Leyes Nuevas

DEIVE, Carlos Esteban. Los guerrilleros negros: esclavos fugitivos y cimarrones en Santo Domingo. Santo Domingo: Fundación Cultural Dominicana, 1989; ALADRÉN, Gabriel. Sem respeitar fé nem tratados: escravidão e guerra na formação histórica da fronteira sul do Brasil (Rio Grande de São Pedro, c. 1777-1835). Tese (doutorado em história) - Programa de Pós-Graduação em História, Universidade Federal Fluminense, Niterói, 2012, p. 134-224; GRINBERG, Keila. Fronteiras, escravidáo e liberdade no sul da América. In: GRINBERG, Keila (Org.). As fronteiras da escravidão e da liberdade no sul da América. Rio de Janeiro: 7Letras, 2013, p. 7-24; RUPERT, Linda M. 'Seeking the water of baptism': fugitive slaves and imperial jurisdiction in the early modern Caribbean. In: BENTON, Lauren e ROSS, Richard J. (Orgs.). Legal pluralism and empires, 1600-1850. Nova York: New York University Press, 2013, p. 199-231.

${ }^{6}$ GRINBERG, Keila. Illegal Enslavement, International Relations, and International Law on the Southern Border of Brazil. Law and History Review, v. 35, n. 1, p. 31-52, 2017.

7 PETIT MUÑOZ, La condición jurídica, social, económica y politica de los negros durante el coloniaje en la Banda Oriental, op. cit., p. 243-247.

${ }^{8}$ Outra fonte de precedentes era a normativa espanhola que sancionava e regulava a existência de comunidades negras formadas originalmente por escravos cimarrones reunidos em palenques, mocambos e quilombos. 
(1542) e da célebre controvérsia entre Ginés de Sepúlveda e Bartolomé de las Casas na Junta de Valladolid (1550-51). ${ }^{9}$ Carlos V e Felipe II emitiram cédulas e provisóes contra a prática da escravização, inclusive dos originários da "demarcação de Portugal". Na década de 1550, índios capturados no Brasil eram vendidos em Margarita, San Juan, Santo Domingo, no Caribe e em Chachapoyas, no Peru. ${ }^{10}$

No mesmo marco se incluem outras disposições registradas durante o século XVII, quando era comum a venda de índios extraídos do Maranhão e das Guianas nas ilhas caribenhas. ${ }^{11}$ Margarita e a pequena ilha de Cubagua, que havia sido o epicentro de uma febril atividade de extração de pérolas no século XVI, eram destinos importantes. Vecinos e o governador de Margarita defendiam a entrada de índios do Brasil, por sua importância para a lavoura e a captura de pérolas. ${ }^{12}$ Segundo John Hemming, o governador do Estado do Maranhão, Francisco Coelho de Carvalho (1626-1636), participou entusiasticamente do tráfico. ${ }^{13}$ Os monarcas espanhóis, ao longo do século XVII, reiteraram continuadamente a obrigação de libertar os provenientes dos domínios de Portugal, mas a atividade persistia, particularmente em regiôes de fronteira, onde havia escassa presença da autoridade real e fortes interesses econômicos em torno do negócio. ${ }^{14}$

Petit Muñoz identifica a normativa sobre os índios como fonte jurídica direta do asilo aos escravos africanos. No entanto, não compartilho integralmente de sua posição, pois a base jurídica e religiosa que fundamentava as disposiçôes sobre os índios era a concepção que assegurava a liberdade em suas terras de origem. Já em relação aos africanos, apesar de contestaçóes eventuais ao seu cativeiro e da discussão, restrita, sobre os critérios que regulavam o tráfico, não prevaleceu no mundo ibérico, quer no campo do direito, quer na esfera da ação

\footnotetext{
${ }^{9}$ Veja-se exemplos significativos, entre cédulas, ordens, cartas, instruções e provisóes reais em ENCINAS, Diego de. Cedulario Indiano. Madri, 1596, p. 361-381. v. 4. A controvérsia de Valladolid foi examinada por PAGDEN, Anthony. La caida del hombre natural: el indio americano y los orígenes de la etnología comparativa. Madri: Alianza Editorial, 1988, p. 169-199.

10 "Carta do Emperador don Carlos a audiencia de Santo Domingo, Valladolid, 07/07/1550". In: ENCINAS, Diego de. Cedulario Indiano, op. cit., p. 373-374. "Real Cédula, Valladolid, 16/07/1550”. In: LUCENA SALMORAL, Manuel. Leyes para esclavos. Madri: Fundación Histórica Tavera, 2000, p. 696-697. "Real Cédula, Valladolid, 21/09/1556”. In: ENCINAS, Diego de. Cedulario Indiano, op. cit., p. 377-379. A provisão de 07/07/1550 e a cédula de 21/09/1556 foram editadas como Lei V, Título segundo, De la libertad de los indios, do Livro VI da Recopilación de Leyes de los Reynos de las Indias, Tomo Segundo. Madri, 1681, p. 195 ("Que los indios del Brasil, o demarcación de Portugal, sean libres en las Indias".

11 "Real Cédula, Madri, 20/12/1609. In: LUCENA SALMORAL, Manuel. Leyes para esclavos, op. cit., p. 825; "Real Instrucción, San Lorenzo, 18/08/1617”. Ibidem, p. 835.

12 "Mandamiento Real" e "Real Cédula", Madri, 18/05/1629. Ibidem, p. 851-852. Esta cédula também consta da Recopilación: Lei IV, Título segundo, do Livro VI da Recopilación de Leyes de los Reynos de las Indias, op. cit., p. 195. Sobre a extração de pérolas em Cubagua e Margarita cf. GARAVAGLIA, Juan Carlos e MARCHENA, Juan. América Latina de los orígenes a la independencia. Barcelona: Crítica, 2005, p. 129-130. v. 1.

${ }^{13}$ HEMMING, John. Red gold: the conquest of the Brazilian Indians. Cambridge: Harvard University Press, 1978, p. 219-230.

${ }^{14}$ Na Venezuela, por exemplo: "Real Carta, Madrid, 14/02/1640"; "Real Cédula, Lleida, 08/08/1644”. In: LUCENA SALMORAL, Manuel. Leyes para esclavos, op. cit., p. 855-856; 868.
} 
política, concepçôes e práticas que primassem por sua liberdade. Pelo contrário, predominou ora o silêncio sobre sua condição, ora a defesa da legitimidade de sua escravizaçáa, ao passo que o tráfico transatlântico e os empreendimentos escravistas na América Ibérica deslanchavam. ${ }^{15}$ A relação entre os dois conjuntos de dispositivos legais era indireta. As leis sobre a liberdade dos índios originários de colônias estrangeiras expressavam interesses econômicos e políticos domésticos do império espanhol, enquanto as concernentes aos africanos fugitivos se vinculavam a diretrizes da política internacional.

\section{A emergência da política do asilo, 1680-1701}

No decurso da Guerra dos Trinta Anos (1618-1648), Holanda, Inglaterra e França começaram a reverter a hegemonia ibérica no Novo Mundo. Os norte-europeus fundaram estabelecimentos nas Pequenas Antilhas na década de 1620 e posteriormente expandiram sua presença para lugares como a Jamaica e a Hispaniola. No princípio, os portos serviram de bases para ataques de corsários, mas logo se tornaram centros de um lucrativo contrabando com as colônias espanholas, além de áreas para o cultivo de tabaco e anil. Entre a Paz de Westfália (1648) e a Guerra de Sucessão Espanhola (1702-1713), mudanças profundas ocorreram na economia da Europa ocidental e em seu terreno colonial mais disputado, o Caribe. A Inglaterra e, posteriormente, a França desenvolveram suas colônias caribenhas apostando na produção escravista de açúcar. Ambas, assim como a Holanda, passaram a atuar de forma agressiva no tráfico transatlântico de escravos, a fim de abastecer suas colônias e realizar

\footnotetext{
${ }^{15}$ A discussão sobre a relação entre a liberdade dos índios e a dos africanos é complexa. Para posiçóes que, a despeito de suas diferenças, creio sustentarem minha afirmação cf. DAVIS, David Brion. O problema da escravidão na cultura ocidental, op. cit., p. 193-224; ALENCASTRO, Luiz Felipe de. O trato dos viventes: formação do Brasil no Atlântico Sul, op. cit., p. 155-187; MATTOS, Hebe. A escravidão moderna nos quadros do Império português: o Antigo Regime em perspectiva atlântica. In: FRAGOSO, João; BICALHO, Maria Fernanda; GOUVÊA, Maria de Fátima (Orgs.). O Antigo Regime nos trópicos: a dinâmica imperial portuguesa (séculos XVI-XVIII). Rio de Janeiro: Civilização Brasileira, 2001, p. 141-162; CASTELNAU-L'ESTOILE, Charlotte de. Operários de uma vinha estéril: os jesuítas e a conversão dos índios no Brasil, 1580-1620. Bauru: Edusc, 2006; ZERON, Carlos Alberto. Linha de fé: a Companhia de Jesus e a escravidão no processo de formação da sociedade colonial (Brasil, séculos XVI e XVII). São Paulo: Edusp, 2011, p. 170188; 348-369; MARCOCCI, Giuseppe. Escravos ameríndios e negros africanos: uma história conectada: teorias e modelos de discriminaçáo no império português (ca. 1450-1650). Tempo, v. 16, n. 30, p. 41-70, 2011. Anthony Pagden afirma que os teólogos que tomaram parte nas polêmicas em defesa dos índios demonstraram pouco interesse pelo destino dos africanos. A razáo da diferença radical na opiniáo espanhola entre a escravidão dos africanos e a dos ameríndios remete ao fato de que os primeiros provinham de territórios externos aos domínios espanhóis, de modo que não era responsabilidade dos Reis Católicos assegurar a legitimidade de sua escravização. Os ameríndios, ao contrário, viviam em terras que a coroa espanhola pretendia ocupar com direitos de soberania legítimos. Os índios eram vassalos, de modo que sua condiçáo era crucial para a justificativa que os espanhóis ofereciam a seu império. Cf. PAGDEN, Anthony. La caída del hombre natural: el indio americano y los orígenes de la etnología comparativa, op. cit., p. 57-59.
} 
contrabando com a América espanhola. ${ }^{16}$

Carlos II, o último rei Habsburgo espanhol, enfrentou muitas dificuldades internas e externas. A França emergiu como grande potência da Europa continental desde a Paz dos Pireneus (1659) e, ao longo de seu reinado, Luís XIV pressionou a Espanha visando incorporar territórios e obter vantagens comerciais. No último quartel do século, França e Espanha se enfrentaram em três guerras, concluídas com os tratados de Nijmegen (1678), Ratisbon (1684) e Rijswijk (1697). Carlos II não deixou herdeiros e sua sucessão foi objeto de intensa disputa internacional. Sua morte desencadeou uma guerra que, apesar de vencida pelos Bourbon, teve alto custo. Após os tratados de Utrecht (1713) e Rastatt (1714) a monarquia espanhola perdeu sua condição de potência territorial extrapeninsular na Europa e os ingleses obtiveram vantagens significativas no comércio atlântico. ${ }^{17}$

As primeiras disposiçóes espanholas que outorgavam liberdade a escravos negros fugidos de colônias estrangeiras datam da década de 1680. Trata-se de um contexto marcado pela debilidade política e militar da Espanha, pelo fortalecimento da Inglaterra, França e Holanda no comércio atlântico e pela formação de impérios coloniais norte-europeus estruturados na escravidão e no tráfico transatlântico, particularmente no espaço caribenho. A resposta espanhola a esses desafios foi errática e incluiu, em seu repertório, a política do asilo como instrumento diplomático de pressão e ameaça.

No dia 29 de maio de 1680, Carlos II dirigiu-se ao governador de Trinidad determinando a alforria de todos os negros oriundos de território estrangeiro que chegassem à ilha em busca do batismo. ${ }^{18}$ Excluía-se peremptoriamente do alcance da norma a holandesa Curaçao, certamente porque Espanha e Províncias Unidas mantinham uma relação de proximidade desde meados da década de 1650, forjada no mútuo interesse de se proteger do expansionismo francês. A Paz de Nijmegen recém-encerrara uma guerra em que espanhóis e neerlandeses lutaram juntos contra o exército de Luís XIV. De fato, Carlos II emitiu a cédula para prejudicar os franceses. Os alvos eram a Martinica, que detinha o maior contingente de escravos africanos entre as colônias francesas, St. Vincent e Granada. ${ }^{19}$ Meses depois, a instrução foi reiterada para o governador da Hispaniola, mas sem mencionar a necessidade

16 DAVIES, Kenneth Gordon. The North Atlantic world in the seventeenth century. Mineápolis: University of Minnesota Press, 1974, p. 108-131; BLACKBURN, Robin. A construção do escravismo no Novo Mundo: do barroco ao moderno. Rio de Janeiro: Record, 2003, p. 231-371; STEIN, Stanley J.; STEIN, Barbara Hadley. Silver, trade, and war: Spain and America in the making of early modern Europe. Baltimore: The Johns Hopkins University Press, 2000, p. 34-39; 106-108; BERBEL, Márcia; MARQUESE, Rafael; PARRON, Tâmis. Escravidão e política: Brasil e Cuba, 1790-1850. São Paulo: Hucitec, 2010, p. $42-47$.

${ }^{17}$ RUIZ IBÁNEZE, José Javier; VINCENT, Bernard. Historia de España. Los siglos XVI-XVII: política y sociedad. Madri: Síntesis, 2007, p. 268-299.

18 "Real Cédula, Madrid, 29/05/1680". In: LUCENA SALMORAL, Manuel. Leyes para esclavos, op. cit., p. 921.

${ }^{19}$ Um censo realizado em 1683 recolheu informaçóes de todas as ilhas francesas do Caribe, exceto Saint-Domingue. No total, havia cerca de 13 mil brancos e 19 mil escravos negros. Martinica contava com aproximadamente 9.400 escravos africanos, seguida por St. Christophe e Guadalupe, com pouco mais de 4 mil cada. Cf. DAVIES, Kenneth Gordon. The North Atlantic world in the seventeenth century, op. cit., p. 80-83. 
de conversão. ${ }^{20}$ No mês de junho de 1685, um ano após celebrar a Paz de Ratisbon, o rei espanhol voltou a confirmar a política de asilo em Santo Domingo. ${ }^{21}$ Os franceses vinham expandindo sua presença na banda ocidental da Hispaniola. Em fins da década de 1670, eles já haviam estabelecido quinze povoaçôes, onde viviam cerca de 2 mil escravos, população que alcançaria 9 mil em 1700. A fuga dos escravos para Santo Domingo era comum e, antes das cédulas, os espanhóis os vendiam ou empregavam na reparação das muralhas da cidade. Depois, fundaram o povoado de San Lorenzo de los Minas, que em 1685 já reunia entre cem e cento e cinquenta negros libertos. ${ }^{22}$

Justificar a libertação de escravos fugitivos não era algo trivial em sociedades que reconheciam o direito de propriedade e preservavam relaçôes diplomáticas regulares. É certo que escravos podiam escapar ou ser apresados durante conflitos militares, sítios e batalhas navais. Nestes casos, declarava-se o direito de boa presa e fuga voluntária, o que costumava obstar a restituição. ${ }^{23}$ No entanto, as cédulas aqui analisadas produziam efeitos para tempos de paz. A de 29 de maio de 1680 alegava o batismo e o desejo de conversão ao catolicismo. Já as 3 de setembro do mesmo ano e 1 de junho de 1685 simplesmente afirmavam que a ordem era conveniente para o serviço e a vontade do rei. A França era uma monarquia católica, mas desde o Édito de Nantes (1598) preservava a liberdade de culto dos huguenotes. Apesar de formalmente proibidos de praticarem sua religião nas Antilhas, muitos lá se estabeleceram, o que ocasionou conflitos seguidos com missionários católicos. ${ }^{24} \mathrm{O}$ dominicano Jean-Baptiste $\mathrm{Du}$ Tertre relatou os esforços para catequizar os escravos e sublinhou a resistência dos proprietários protestantes. Eles temiam ser coagidos a libertar seus cativos se os cristianizassem. Em 1685, no mesmo ano em que o Édito de Nantes foi revogado, o ministro das finanças Jean-Baptiste Colbert redigiu o Code noir. Nele, desenhava-se com clareza o projeto católico de colonização das ilhas. Proibiu-se enfaticamente o exercício de outras religióes e os senhores foram obrigados a batizar e instruir seus escravos. ${ }^{25}$ Portanto, se havia escravos negros não batizados nas colônias francesas do Caribe, eles certamente não eram a maioria, por isso o silêncio sobre o catolicismo se tornou a norma nas cédulas que miravam a França.

Tudo seria mais simples na fronteira da Flórida com as colônias inglesas da América do Norte. Os ingleses não cristianizavam seus escravos, pois temiam que a evangelização os tor-

\footnotetext{
20 “Instrucción, Madrid, 03/09/1680". In: LUCENA SALMORAL, Manuel. Leyes para esclavos, op. cit., p. 921-922.

21 "Real Cédula, Madrid, 01/06/1685". Ibidem, p. 930.

${ }^{22}$ DEIVE, Carlos Esteban. Los guerrilleros negros: esclavos fugitivos y cimarrones en Santo Domingo, op. cit., p. 91-113. Cf. também, para os dados demográficos, BLACKBURN, Robin. A construção do escravismo no Novo Mundo: do barroco ao moderno, op. cit., p. 344-357.

${ }^{23}$ ALADRÉN, Gabriel. Sem respeitar fé nem tratados: escravidão e guerra na formação histórica da fronteira sul do Brasil (Rio Grande de São Pedro, c. 1777-1835), op. cit., p. 134-224.

${ }^{24}$ PETITJEAN-ROGET, Jacques. Les protestants à la Martinique sous l'ancien régime. Revue d'histoire des colonies, v. 42, n. 147, p. 220-265, 1955.

${ }^{25}$ MARQUESE, Rafael de Bivar. Feitores do corpo, missionários da mente. Senhores, letrados e o controle dos escravos nas Américas, 1660-1860. São Paulo: Companhia das Letras, 2004, p. 26-36.
} 
nasse indisciplinados e acarretasse prejuízos econômicos. ${ }^{26}$ Nos anos seguintes à fundação de Charleston (1670) houve crescimento expressivo da escravidão africana. Na Carolina do Sul, em 1690, escravos negros somavam 1.500 indivíduos, 40\% do conjunto da população. ${ }^{27}$ Em 1687, um grupo de fugitivos chegou à localidade espanhola de San Agustín, na Flórida, vindo de St. George, na Carolina. Os ingleses tentaram recuperá-los, mas o governador Diego de Quiroga se negou a devolvê-los, afirmando que haviam se convertido ao catolicismo. Quiroga se ofereceu para comprá-los e solicitou assistência do rei sobre como conduzir a matéria. ${ }^{28}$ No dia 7 de novembro de 1693, Carlos II soltou uma real cédula que garantia a liberdade dos escravos e exortava outros que desejassem abraçar a fé católica a seguirem seu exemplo. ${ }^{29}$

A fronteira anglo-espanhola na América do Norte era fonte de disputas diplomáticas e militares. Nas décadas de 1670 e 1680, ocorreram ataques mútuos, pirataria e conflitos que envolviam alianças com indígenas. A política espanhola de oferecer alforria aos escravos fugitivos visava provocar prejuízos aos ingleses, além de atraí-los para tarefas de povoamento e defesa. Contudo, no início da década de 1690, as relaçôes entre Inglaterra e Espanha melhoraram. Ambas aderiram à Liga de Augsburg, em oposição à França na Guerra dos Nove Anos (1688-1697), inaugurando um período de paz frágil na América do Norte. Os ingleses demonstraram boa vontade, punindo corsários e piratas que atacavam estabelecimentos espanhóis na Flórida. A emissão da cédula de 1693, uma ameaça aos interesses dos proprietários de escravos das Carolinas, foi acompanhada por medidas favoráveis às relaçóes anglo-espanholas na região, como a restituiçãa de prisioneiros ingleses. $\mathrm{O}$ rei espanhol também ordenou o pagamento de indenização pela libertação dos fugitivos de $1687 .{ }^{30}$

A política de asilo podia ser revogada ou suspensa por novas cédulas reais ou pela assinatura de convênios bilaterais. O Tratado de Rijswijk (1697) havia assegurado o domínio francês sobre São Domingos, permitindo que a diplomacia de Luís XIV passasse a trabalhar com afinco pela sucessão da Coroa espanhola. O Conselho de Estado de Carlos II defendeu o candidato Philippe d'Anjou, avaliando que a aliança com a França seria a melhor maneira de preservar a integridade do império espanhol. ${ }^{31}$ Ao mesmo tempo, na Hispaniola, franceses e espanhóis percebiam as vantagens de manter boas relaçóes. A expansão da agricultura escravista em São Domingos criou um mercado para os couros e o gado dos colonos espa-

\footnotetext{
${ }^{26}$ Ibidem, p. 42-46.

${ }^{27}$ MENARD, Russell R. Slave demography in the Lowcountry, 1670-1740: from frontier society to plantation regime. The South Carolina Historical Magazine, v. 96, n. 4, p. 280-303, 1995.

${ }^{28}$ LANDERS, Jane. Spanish sanctuary: fugitives in Florida, 1687-1790, op. cit., p. 296-313.

${ }^{29}$ Não pude localizar a cédula original, mas encontrei uma transcrição vertida para o inglês: "The King. To my Governor and Captain-General of the City of St. Augustine in the Province of Florida, and Field Marshal Don Diego de Quiroga y Losada, in whose charge that Government is now". In: BROOKS, A. M. The unwritten history of Old St. Augustine. St. Augustine: Record Co., s. d., p. 145-146.

${ }^{30}$ GRADY, Timothy Paul. Anglo-Spanish rivalry in Colonial South-East America, 1650-1725. Londres: Pickering \& Chatto, 2010, p. 67-75.

${ }^{31}$ ELLIOTT, John H. Imperial Spain, 1469-1716. Londres: Penguin Books, 2002, p. 373-375.
} 
nhóis. $\mathrm{O}$ intercâmbio comercial e a correspondência entre as autoridades das duas colônias avolumaram. A pressão diplomática do governo de Luís XIV, que chegou a enviar um procurador a Madri, teve êxito e Carlos II publicou em março de 1700 uma cédula ordenando a devolução dos escravos pertencentes aos franceses. ${ }^{32}$

$\mathrm{Na}$ Flórida a situação era um pouco diferente. Sabe-se que pelo menos quatro grupos de escravos fugitivos chegaram a San Agustín depois de 1688 e num único caso houve devolução. ${ }^{33}$ Apesar das diferenças entre a Flórida e Santo Domingo - determinadas, em grande medida, pelos distintos alinhamentos diplomáticos com Inglaterra e a França —, nos dois lugares a observância das leis sobre os escravos fugitivos - quer quando favoráveis à liberdade, quer quando favoráveis à restituição - era parcial e dependia de interesses e arranjos locais.

O último quartel do século XVII foi a época decisiva para o surgimento das leis de liberdade a escravos fugitivos de colônias estrangeiras e para a emergência de uma política de asilo da Coroa espanhola. No Caribe e na Flórida brotaram espontaneamente e quase simultaneamente práticas de concessão de alforria a cativos evadidos das possessóes francesas e inglesas, como parte de um conjunto de respostas locais e contingentes de colonos e administradores espanhóis à nova dinâmica das fronteiras internacionais com impérios escravistas hostis. Estas iniciativas difusas foram transpostas e articuladas no plano da política internacional da monarquia espanhola, onde adquiriram sentido global, com características, funções e um padrão de aplicação relativamente bem estabelecido. O que era reação espontânea, local e contingente se transformou em política diplomática da Coroa.

Nos momentos marcados pela pacificação das relaçôes com outros Estados, mas com permanência de tensôes e rivalidade, recorria-se às medidas de asilo como ameaça e instrumento de pressão. Foi o que ocorreu quando a Espanha assinou tratados de paz com a França - as cédulas de 1680 foram emitidas logo depois da Paz de Nijmegen e a de 1685 um ano após a Paz de Ratisbon - e quando forjou uma aliança precária com a Inglaterra — a cédula de 1693 apareceu quando ambas participavam juntas da Liga de Augsburg. As mesmas cédulas, ou seus efeitos, podiam ser revogadas ou suspensas, assim que as relaçóes se firmassem em terreno mais amigável, como ocorreu com a França no ano de 1700.

\section{O asilo contra os hereges, 1733-1753}

No início do setecentos, a fuga de escravos mantinha-se como fenômeno comum nas

\footnotetext{
32 "Real Cédula, Madrid, 06/03/1700". In: LUCENA SALMORAL, Manuel. Leyes para esclavos, op. cit., p. 942; DEIVE, Carlos Esteban. Los guerrilleros negros: esclavos fugitivos y cimarrones en Santo Domingo, op. cit., p. 115-125.

${ }^{33}$ LANDERS, Jane. Gracia Real de Santa Teresa de Mose: a free black town in Spanish colonial Florida. The American Historical Review, v. 95, n. 1, p. 14-15, 1990.
} 
fronteiras coloniais dos impérios atlânticos, ${ }^{34}$ mas a política espanhola de asilo só foi recuperada na década de 1730. A Guerra de Sucessão Espanhola havia conferido à Inglaterra enormes vantagens, como o asiento de escravos e o navio de permiso, que permitiam abocanhar uma fatia do lucrativo mercado hispano-americano. Felipe $\mathrm{V}$ tentou reverter ou pelo menos mitigar esses prejuízos, provocando dois momentos de conflito com a Grá-Bretanha (17181720 e 1725-1729). ${ }^{35}$ A disputa territorial na América do Norte também produzia tensôes. A Espanha ficou muito descontente com a fundação da Geórgia, em 1732. Segundo John Elliott, ao contrário do típico padrão inglês de colonização, em que a fundação de novas colônias respondia à pressão de colonos por terras, o caso da Geórgia obedeceu a imperativos geopolíticos. George II visava criar uma zona de contençáo para barrar o expansionismo de franceses e espanhóis. ${ }^{36}$

A política espanhola para os escravos fugitivos na Flórida acompanhou a dinâmica cambiante das relaçóes anglo-espanholas. O Conselho de Índias se reuniu em abril de 1731 para avaliar a situação de escravos que haviam chegado a San Agustín na década de 1720. O governador Antonio de Benavides libertara alguns e vendera outros para indenizar seus proprietários. Ele alegava que a cédula de 1693 só deveria vigorar durante a guerra. O fiscal do Conselho referendou sua posição e lembrou que na Hispaniola prevalecia a restituição, uma conduta amigável praticada entre soberanos e potências em tempos de paz. Abria-se uma exceção somente quando os escravos fugiam em busca do batismo. Nestes casos, o fiscal recomendava a alforria e a indenização aos proprietários, tendo cuidado de averiguar se o desejo de conversão não era simulado. Os conselheiros não aprovaram a proposta do fiscal, pois a Espanha não deveria oferecer à Grã-Bretanha "motivo de desconfiança e queixa". Portanto, a Flórida não poderia estabelecer uma providência permanente para "atrair e reter todos os escravos fugitivos que viessem do território que ocupam os ingleses". ${ }^{37}$

A posiçấo do Conselho de Índias durou pouco. A fundação da Geórgia demonstrou que os britânicos não tinham o mesmo zelo pela boa correspondência com as nações amigas. A resposta espanhola veio na forma de duas cédulas promulgadas em outubro de 1733. Felipe V oferecia a liberdade aos fugitivos que chegassem à Flórida em busca do batismo e proibia o

\footnotetext{
${ }^{34}$ Nas primeiras décadas do setecentos, na Hispaniola, na Colônia do Sacramento e em Curaçao escravos fugitivos de franceses, portugueses e holandeses eram eventualmente libertados, mas não como parte de uma política oficial abrangente. Eles recebiam alforria durante guerras e cercos militares. Cf. DEIVE, Carlos Esteban. Los guerrilleros negros: esclavos fugitivos y cimarrones en Santo Domingo, op. cit., p. 127-141; ALADRÉN, Gabriel. Sem respeitar fé nem tratados: escravidão e guerra na formação histórica da fronteira sul do Brasil (Rio Grande de São Pedro, c. 1777-1835), op. cit., p. 141-143; RUPERT, Linda M . 'Seeking the water of baptism': fugitive slaves and imperial jurisdiction in the early modern Caribbean, op. cit., p. 209-210.

${ }^{35}$ BLACK, Jeremy. Trade, empire and British foreign policy, 1689-1815. Londres: Routledge, 2007, p. 121-132. ${ }^{36}$ ELLIOTT, John H. Empires of the Atlantic world: Britain and Spain in America, 1492-1830. New Haven: Yale University Press, 2006, p. 273.

37 "El Consejo de Indias a S. M., Madrid, 12/04/1731". In: WRIGHT, Irene A. Dispatches of Spanish officials bearing on the free negro settlement of Gracia Real de Santa Teresa de Mose, Florida. The Journal of Negro History, v. 9, n. 2, p. 166-172, 1924.
} 
pagamento de indenização aos proprietários ingleses. Por outro lado, condicionava a alforria à prestação de quatro anos de serviço real. Em 1738, o governador da Flórida fundou um povoado fortificado, Gracia Real de Santa Teresa de Mose, para instalar os libertos e auxiliar na defesa contra os ataques britânicos. ${ }^{38} \mathrm{~A}$ deflagração da guerra em 1739 tornaria as relaçóes anglo-espanholas ainda mais tensas, com desdobramentos militares na América do Norte. Novas cédulas foram expedidas em 1740, reiterando a oferta da liberdade para escravos ingleses desejosos de abraçar a fé católica. ${ }^{39}$

A Guerra da Orelha de Jenkins (1739-1748) foi ocasionada por disputas em torno do asiento e dos privilégios comerciais britânicos na América Espanhola, mas logo se combinou com a Guerra de Sucessão da Áustria (1740-1748). O tratado de Aix-la-Chapelle (1748) foi firmado relutantemente por Fernando VI, por não tratar das questóes coloniais, que só seriam solucionadas com a extinção dos direitos britânicos ao asiento ditada pelo acordo de outubro de $1750 .{ }^{40} \mathrm{O}$ estado de guerra havia provocado importantes alteraçóes no comércio colonial espanhol. Para proteger seus navios dos ataques britânicos, a Espanha abandonara o sistema de frotas em prol dos registros sueltos. Isso dinamizou o comércio colonial e favoreceu os franceses que atuavam no mercado hispano-americano por meio de sólidos contatos com negociantes de Cádiz. ${ }^{41}$ Britânicos e holandeses, por outro lado, recorreram de forma mais acentuada ao contrabando, muitas vezes em parceria, reforçando os laços mercantis e financeiros que ligavam Amsterdã e Londres desde a Revolução Gloriosa. ${ }^{42}$

Nesse contexto, a cédula de 24 de setembro de 1750 foi o ponto alto da política de asilo direcionada aos impérios protestantes. Lembrando os precedentes estabelecidos pelas cédulas de 1680, 1693, 1733 e 1740, Fernando VI anunciava de maneira radical: todos os escravos provenientes das colônias inglesas e holandesas que se refugiassem nas colônias espanholas para abraçar a Santa Fé Católica seriam libertados, sem indenização. O texto sublinhava que a norma valeria "para sempre", em tempo de paz ou de guerra, por ser conveniente ao serviço de Deus e do Rei. Ficava expressamente proibido maltratar, restituir ou reduzir à escravidão os fugitivos. Os efeitos da cédula alcançavam todas as províncias da Nova Espanha. ${ }^{43}$ Três anos depois, a norma foi estendida aos vice-reinos do Peru e da Nova Granada. ${ }^{44}$

\footnotetext{
${ }^{38}$ LANDERS, Jane. Gracia Real de Santa Teresa de Mose: a free black town in Spanish colonial Florida, op. cit., p. 17-18.

${ }^{39}$ Não pude localizar as cédulas de 11 de março e 11 de novembro de 1740, mas delas há notícia em outros documentos: "El Gobernador de la Florida D. Manuel de Montiano a S. M., Flórida, 06/05/1741". In: WRIGHT, Irene A. Dispatches of Spanish officials bearing on the free negro settlement of Gracia Real de Santa Teresa de Mose, Florida, op. cit., p. 148; 182-183.

${ }^{40}$ WALKER, Geoffrey J. Spanish politics and imperial trade, 1700-1789. Londres: Macmillan, 1979, p. 210-217.

${ }^{41}$ PEARCE, Adrian J. The origins of Bourbon reform in Spanish South America, 1700-1763. Nova York: Palgrave Macmillan, 2014, p. 126-134; 168-169.

${ }^{42}$ MORGAN, Kenneth. Anglo-Dutch economic relations in the Atlantic World, 1688-1783. In: KLOOSTER, Wim; ROITMAN, Jessica V. (Orgs.). Dutch Atlantic connections, 1680-1800. Leiden: Brill, 2014, p. 119-138.

43 “Real Cédula Buen Retiro, 24/09/1750”. In: LUCENA SALMORAL, Manuel. Leyes para esclavos, op. cit., p. 974-975.

44 “Real Cédula, Buen Retiro, 21/10/1753”. Ibidem, p. 977.
} 
O impacto foi visível. $\mathrm{Na}$ ilha de Curaçao, relatos de proprietários e autoridades holandesas afirmam que na década de 1750 teve início um movimento de fuga massiva para a Venezuela. A fuga de escravos da Jamaica para Cuba também aumentou e até mesmo a luterana Dinamarca, que a princípio não seria atingida pelo decreto, sofreu consequências. Nas ilhas de St. Thomas, St. Jan e St. Croix a evasão de escravos para Porto Rico cresceu e circulavam rumores de que bastava servir um ano ao rei da Espanha para receber a alforria. ${ }^{45}$

Por mais que as rivalidades e os alinhamentos da política internacional se mostrassem inconstantes, pode-se dizer que da década de 1730 até meados da década de 1750 a Espanha consolidou a política de asilo como recurso diplomático contra os impérios cuja religião oficial era protestante, como a Inglaterra e a Holanda. O rei oferecia a alforria a todos os que buscavam o batismo e as cédulas de 1733, 1740, 1750 e 1753 eram justificadas pelas causas da evangelização e da defesa da Religião Católica.

\section{Uma só política para todas as fronteiras, 1763-1789}

A Guerra dos Sete Anos (1756-1763) provocou importantes transformaçóes nas relaçóes diplomáticas dos impérios europeus e na interação entre as metrópoles e suas colônias. No Mundo Ibérico, as consequências do conflito geraram condiçôes para a promoçáo de reformas que visavam reforçar o poder das coroas e aumentar a arrecadação dos cofres régios. As diretrizes da política econômica de Carlos III causaram impacto no fenômeno da fuga de escravos e na utilização diplomática do direito de asilo. A reforma do sistema comercial e o incentivo à expansão da escravidão fortaleceram demográfica e economicamente áreas periféricas do império, justamente onde a acolhida aos fugitivos contribuía para o povoamento e a defesa das fronteiras. Ao mesmo tempo, colonos, administradores e Coroa reforçaram seu comprometimento com a escravidão, uma instituição cuja legitimidade, organização e controle dependiam de arranjos e articulaçóes interimperiais. ${ }^{46}$

A Espanha, apesar de ter lutado ao lado da França na Guerra dos Sete Anos, procurava balancear sua posição no sistema interestatal. A intenção era dispor de autonomia para reformar o sistema de comércio imperial, o que prejudicaria interesses da comunidade mercantil de Cádiz, ligada a casas comerciais francesas e beneficiada pelo monopólio do regime de porto único. Desde a renovação do Pacto de Família (1761), a França lutou para influenciar a política econômica espanhola de modo a obter novas vantagens comerciais e financiar os

${ }^{45}$ AIZPURÚA, Ramón. Esclavitud, navegación y fugas de esclavos en el Curazao del siglo XVIII. In: DALlA CORTE, Gabriela (Org.). Poder local, poder global en América Latina. Barcelona: UBe, 2008, p. 90; RUPERT, Linda M. 'Seeking the water of baptism': fugitive slaves and imperial jurisdiction in the early modern Caribbean, op. cit., p. 211-212; HALL, N. A. T. Maritime maroons: 'grand marronage' from the Danish West Indies. The William and Mary Quarterly, v. 42, n. 4, p. 484-485, out. 1985.

${ }^{46}$ Sobre as reformas, cf. ADELMAN, Jeremy. Sovereignty and revolution in the Iberian Atlantic. Princeton: Princeton University Press, 2006, p. 13-100 e BERBEL, Márcia; MARQUESE, Rafael; PARRON, Tâmis. Escravidão e política: Brasil e Cuba, 1790-1850, op. cit., p. 75-85. 
custos da guerra, mas encontrou forte resistência. As relaçóes franco-espanholas se deterioram ainda mais com a crise das Malvinas (1770-1771). ${ }^{47}$

$\mathrm{Na}$ mesma época, a antiga disputa hispano-portuguesa pela Colônia do Sacramento e pelos territórios das fronteiras do Rio da Prata entrou numa fase de crescente tensão, que culminou em 1773 com uma "guerra náo declarada". Apesar da paz de 1763, os litígios territoriais não foram resolvidos e nos anos seguintes a região foi palco de conflitos e movimentaçôes militares. $\mathrm{O}$ aumento do roubo de gado nas áreas contestadas levou Madri a ordenar, em 1772, que o governador de Buenos Aires, Juan José de Vértiz, organizasse uma coluna para coibir as atividades portuguesas. No ano seguinte, os espanhóis erigiram na fronteira o forte de Santa Tecla e entraram em confronto com guerrilhas luso-brasileiras. ${ }^{48}$

A crise das Malvinas e a retomada das hostilidades no Rio da Prata levaram Carlos III a promulgar uma nova cédula em fevereiro de 1773 . No ano anterior, o governador de Trinidad solicitara a Madri instruçôes sobre como proceder em relaçáo a escravos fugidos de Tobago, então sob domínio britânico, e Essequibo, colônia holandesa. O mais notável desta cédula é que, pela primeira vez, a Coroa espanhola estabelecia uma política geral de libertação de escravos fugitivos de colônias estrangeiras sem nenhuma fundamentação religiosa. Uma vez que os escravos eram ingleses e holandeses, Carlos III poderia simplesmente reproduzir o argumento utilizado desde 1693. No entanto, como visava retaliar também a França e Portugal, monarquias católicas, foi excluída qualquer menção ao batismo na cédula. Negras e negros escravizados deveriam ser libertados porque o "direito de gentes" assim determinava, pelo simples fato de terem adentrado os domínios espanhóis. O rei os admitia com "suma clemência", sob sua "real proteção e amparo", exigindo apenas que se portassem como fiéis e agradecidos vassalos e mantivessem uma ocupação. ${ }^{49}$ É verdade que decretos anteriores, na Hispaniola e no Rio da Prata, libertavam fugitivos utilizando argumentos como a proteçấo contra maus-tratos e castigos excessivos, mas eram medidas circunscritas e usualmente se confundiam com disposiçóes excepcionalmente aplicadas durante conflitos militares. A cédula de 20 de fevereiro de 1773 significava uma alteração profunda na política espanhola de asilo, que agora prescindia do apelo religioso ${ }^{50}$ e podia ser usada contra todos

\footnotetext{
${ }^{47}$ DELGADO RIBAS, Josep M. Dinámicas imperiales (1650-1796). España, América y Europa en el cambio institucional del sistema colonial español. Barcelona: Bellaterra, 2007, p. 340-356.

${ }^{48}$ ALDEN, Dauril. The undeclared war of 1773-1777: climax of Luso-Spanish Platine rivalry. The Hispanic American Historical Review, v. 41, n. 1, p. 55-74, 1961.

49 "Real Cédula, El Pardo, 20/02/1773". In: LUCENA SALMORAL, Manuel. Leyes para esclavos, op. cit., p. 1020. ${ }^{50}$ Os interesses diplomáticos costumavam prevalecer sobre a norma legal, mas não sem algum constrangimento, por isso foi significativo o abandono da justificativa religiosa. Veja-se um exemplo: em 1766 chegaram à Guiana espanhola nove negros fugitivos da francesa Caiena e três da holandesa Essequibo. Os holandeses foram libertados, por desejarem "abraçar a fé católica". Os franceses já eram católicos, de modo que as cédulas não poderiam lhes beneficiar, por isso foram devolvidos. Neste caso, não houve qualquer descompasso entre alinhamento diplomático (anti-Holanda e pró-França) e a lei. Quando havia, ajustava-se, em favor das diretrizes da política exterior: em 1767, seis escravos fugidos da então britânica ilha de Granada chegaram a Cumaná. Quatro pediram o batismo e dois já eram católicos. Inicialmente, as normas legais foram seguidas: os pagáos seriam alforriados e os católicos devolvidos. Contudo, depois de consulta ao Conselho de Índias, os dois católicos também foram libertados, sob alegação de que náo lhes era permitido exercer livremente sua religião (assistir à missa e
} 
os impérios escravistas rivais, do Caribe ao Rio da Prata.

As reformas promovidas durante o reinado de Carlos III retomaram impulso na década de 1770. Sob direção do conde de Floridablanca e de José de Gálvez foram implementadas mudanças no sistema comercial, na arrecadação fiscal e na organização militar e administrativa do império espanhol, especialmente nos domínios americanos. A Espanha e a França apoiaram os Estados Unidos na guerra de independência e as dificuldades enfrentadas pela Grã-Bretanha ajudaram a dinamizar o comércio colonial espanhol, que funcionava desde 1778 sob o regime do comercio libre. Contudo, nos últimos anos da década de 1780 a renovação apresentava sinais de esgotamento. A morte de Gálvez, em 1787, levou a administração espanhola a impulsionar uma nova onda de reformas, com o objetivo de ampliar o sistema do comercio libre e incentivar o crescimento econômico das colônias espanholas. ${ }^{51}$

A escravidão estava no centro das preocupaçóes. Em fevereiro de 1789, Carlos III liberou o tráfico negreiro em Cuba, Santo Domingo, Porto Rico e Venezuela. Em maio, promulgou a Instrucción para la educación, trato y ocupaciones de los esclavos, um código para regulamentar o tratamento dos cativos nas colônias espanholas. Antes, no dia 14 de abril, o rei havia lançado o que seria a derradeira cédula de libertação de escravos fugidos de colônias estrangeiras. Os argumentos do texto de 1773 se repetiam: não havia qualquer menção ao batismo ou à religião católica e o direito de gentes legitimava a recuperação da "natural liberdade" dos negros fugitivos. ${ }^{52}$ Vistas em conjunto, as cédulas de 1773 e 1789 representam o zênite da política de asilo: fundadas no princípio abstrato do direito de gentes, seus efeitos eram amplos e determinavam a libertação imediata, irrevogável e incondicional de todo e qualquer escravo negro evadido de território estrangeiro que alcançasse os domínios espanhóis no Novo Mundo. No entanto, como sói ocorrer em processos históricos, no mesmo momento em que um fenômeno aparentemente está no auge de sua força, estão em curso tendências que provocarão a sua derrocada.

\section{O fim da política de asilo na era das revoluções}

A política de asilo foi minada por tratados bilaterais para devolução de escravos fugitivos. Percebe-se, desde fins da década de 1760, uma multiplicação de acordos deste teor, fruto de uma pressão cada vez maior de colonos, administradores e diplomatas estrangeiros, mas também, o que talvez pareça surpreendente, de espanhóis e hispano-americanos. Em 1767,

guardar domingos e dias santos). Neste caso, como houve conflito, reinterpretou-se a norma legal para adequá-la às diretrizes diplomáticas. Cf. ANDRÉS-GALLEGO, José. La esclavitud en la monarquia hispánica. Madri: Fundación Ignacio Larramendi/Fundación MAPFRE Tavera, 2005 [CD-ROM], p. 107-109.

${ }^{51}$ DELGADO RIBAS, Josep M. Dinámicas imperiales (1650-1796), op. cit., 2007, p. 457-568.

52 "Real Cédula, Madrid, 14/04/1789". In: LUCENA SALMORAL, Manuel. Leyes para esclavos, op. cit., p. $1147-1150$. 
Dinamarca e Espanha firmaram convênio para mútua restituição de escravos entre Porto Rico e as ilhas de St. Croix, St. Thomas e St. Jan. Em 1777, foi celebrado um tratado com a França, respectivo à ilha Hispaniola e outro com Portugal, sobre o Rio da Prata. ${ }^{53}$ Em dezembro de 1783 o governador de Trinidad foi orientado a devolver escravos fugidos sempre que reclamados com justificativa. ${ }^{54}$ No ano seguinte, autoridades da ilha propuseram firmar convênios oficiais com holandeses, ingleses e franceses dispondo sobre o assunto. Na Venezuela, funcionários, militares e proprietários locais solicitaram em 1771 e novamente em 1784 que a Coroa assinasse uma convenção com as potências estrangeiras para a mútua restituição de escravos. ${ }^{55}$ $\mathrm{Na}$ mesma época, colonos holandeses em Essequibo e Demerara solicitavam à Companhia das Índias Ocidentais (WIC) mediação oficial com a Espanha para evitar as fugas. ${ }^{56} \mathrm{Na}$ Flórida, o governo espanhol restabelecido em 1784 instituiu normas para o controle dos negros livres, exigindo documentos comprobatórios de sua condição. Autoridades dos Estados Unidos pressionaram pelo fim do asilo e proprietários estadunidenses reclamaram a devolução de escravos fugidos ou roubados pelos ingleses durante a guerra de independência. ${ }^{57}$

Como explicar a proliferação de acordos oficiais de restituição? Para Alvin Thompson, era uma reação aos problemas cada vez mais graves que os espanhóis enfrentavam com comunidades quilombolas em seu próprio território. ${ }^{58}$ Segundo Linda Rupert, a Coroa espanhola começou a enxergar os escravos fugitivos estrangeiros como desleais e potencialmente perigosos. ${ }^{59}$ Ambos estão corretos, mas a mudança de atitude dos espanhóis era uma expressão de transformaçóes estruturais ocorridas depois da Guerra dos Sete Anos. A política de asilo, desde o fim do século XVII, articulava diretrizes diplomáticas à necessidade de povoamento e defesa de zonas periféricas nas fronteiras do Império Espanhol. A atração, o assentamento e, eventualmente, o recrutamento dos fugitivos permitiam a incorporação de novos súditos e o fortalecimento da autoridade da Coroa em áreas disputadas e pouco povoadas. Na segunda metade do século XVIII, foi justamente em regióes periféricas como

\footnotetext{
53 "Convenio entre las coronas de España y de Dinamarca para la mutua restitución de esclavos y desertores en la isla de Puerto Rico y en las danesas de Santa Cruz, Santo Tomás y San Juan, Madrid, 21/07/1767”; “Tratado entre los reyes de España y Francia sobre varios puntos de policía y buena vecindad entre los respectivos súbditos habitantes en la isla de Santo Domingo, Aranjuez, 03/06/1777"; "Tratado preliminar de límites en la América meridional ajustado entre las coronas de España y de Portugal, San Ildefonso, 01/10/1777”. In: CANTILLO, Alejando del. Tratados, convenios y declaraciones de paz y de comercio que han hecho con las potencias extranjeras los monarcas españoles de la Casa de Borbón. Madri: Alegria y Charlain, 1843, p. 507-509; 534-537; 537-544.

54 "Real Cédula, Madrid, 24/11/1783". In: LUCENA SALMORAL, Manuel. Leyes para esclavos, op. cit., p. 1026 e 1149.

${ }^{55}$ RUPERT, Linda M. 'Seeking the water of baptism': fugitive slaves and imperial jurisdiction in the early modern Caribbean, op. cit., p. 215-216.

${ }^{56}$ THOMPSON, Alvin O. Flight to freedom: African runaways and maroons in the Americas. Kingston: University of the West Indies Press, 2006, p. 276.

${ }^{57}$ LANDERS, Jane. Spanish sanctuary: fugitives in Florida, 1687-1790, op. cit., p. 304-309.

${ }^{58}$ THOMPSON, Alvin O. Flight to freedom: African runaways and maroons in the Americas, op. cit., p. 277.

${ }^{59}$ RUPERT, Linda M. 'Seeking the water of baptism': fugitive slaves and imperial jurisdiction in the early modern Caribbean, op. cit., p. 215.
} 
Cuba, Venezuela e Rio da Prata que houve uma combinação de crescimento demográfico e expansão de uma escravidão de novo tipo, agora em plena simbiose com o capitalismo mercantil, ao contrário do modelo "barroco" que antes a caracterizava no mundo hispânico. ${ }^{60}$

A nova realidade comprometeu colonos, autoridades e a própria Coroa com a defesa da escravidão, uma instituição cada vez mais importante na economia da América espanhola. As instruçóes que Carlos III enunciou em 1783 para incentivar o povoamento e o desenvolvimento de Trinidad refletem de forma cristalina a situação: o comércio negreiro na ilha seria liberado e não pagaria direitos por dez anos; os colonos deveriam se armar para reprimir qualquer "alteração" dos escravos; os senhores e o governador elaborariam, da maneira que mais lhes conviesse, um código para normatizar o tratamento e evitar a fuga dos cativos; por fim, o governador deveria observar a devolução de negros fugitivos das ilhas estrangeiras. ${ }^{61}$ Era um pacote completo para o desenvolvimento e a segurança da escravidão colonial, pois combinava incentivo ao tráfico, apoio à agricultura mercantil, autonomia senhorial para controlar e disciplinar os escravos e obediência às normas que regulavam o sistema interestatal. De todo modo, as pressóes derivadas do crescente envolvimento econômico e social dos espanhóis e hispano-americanos com a escravidão não tiveram o condão de, por si só, derrubar a política do asilo. O golpe fatal foi desferido pela combinação de dois eventos que transformaram radicalmente a ordem internacional: a Revolução Francesa e a Revolução do Haiti.

A cédula de 14 de abril de 1789 teve vida curta e foi anulada em maio do ano seguinte, sob alegação de que não existiam ocupaçôes para empregar os escravos fugitivos. ${ }^{62}$ Manuel Lucena Salmoral, ao comentar a mudança repentina e os argumentos vazios utilizados para justificar a revogação, sugeriu tratar-se de uma reação à Revoluçâo Francesa. ${ }^{63}$ Ada Ferrer demonstrou que autoridades em Madri e em Havana passaram a associar os "negros franceses" à circulação de ideias perigosas que estariam promovendo turbulências e sedição na França e em São Domingos. Os proprietários cubanos estavam particularmente alarmados, pois temiam que a acolhida aos fugitivos colocasse em risco a crescente prosperidade da ilha. A ordem de suspensão de maio de 1790 foi reforçada com a proibição da entrada de todo e qualquer negro ou mulato francês, independentemente de sua condição jurídica. Em dezembro de 1791, o interdito incluiu todos os crioulos educados em colônias estrangeiras. ${ }^{64}$

\footnotetext{
${ }^{60}$ ADELMAN, Jeremy. Sovereignty and revolution in the Iberian Atlantic, op. cit., p. 56-100; BLACKBURN, Robin. A construção do escravismo no Novo Mundo: do barroco ao moderno, op. cit.

61 "Real Cédula, Madrid, 24/11/1783". In: LUCENA SALMORAL, Manuel. Leyes para esclavos, op. cit., p. 1026.

62 "Real Orden, Aranjuez, 17/05/1790". Ibidem, p. 1158.

${ }^{63}$ Ibidem, p. 351.

${ }^{64}$ FERRER, Ada. Freedom's mirror: Cuba and Haiti in the age of revolution. Cambridge: Cambridge University Press, 2014, p. 60-63. O papel da oligarquia açucareira cubana foi fundamental: seus representantes no Ayuntamiento de Havana também impediram a publicação da Instrucción para la educación, trato y ocupaciones de los esclavos, vista como tentativa de interferência do Estado espanhol na relação doméstica entre senhores e escravos. Cf. MARQUESE, Rafael de Bivar. Feitores do corpo, missionários da mente. Senhores, letrados e o controle dos escravos nas Américas, 1660-1860, op. cit., p. 197-210.
} 
A cédula de maio de 1790 circulou amplamente pelas províncias do império espanhol e inclusive fora dele. Senhores e autoridades hispano-americanos e estrangeiros receberam a notícia com alívio e satisfação. O governador de Caracas anunciou a medida em julho e imediatamente autorizou a devolução de sete escravos fugidos de Curaçao. ${ }^{65}$ Em junho de 1791, Espanha e Holanda assinaram um convênio de restituição. ${ }^{66} \mathrm{O}$ governador da Flórida deu ampla publicidade à cédula e remeteu cópias para gazetas da Carolina do Sul e da Geórgia. Thomas Jefferson, recém-empossado secretário de Estado, congratulou o governador espanhol e afirmou que a nova postura era essencial para a boa relação entre as duas naçôes. ${ }^{67} \mathrm{O}$ governador do Paraguai, em conluio com autoridades portuguesas, sequer colocou a cédula de 1789 em vigor. Antes de ser informado da revogação ele já havia pleiteado a anulação, com apoio do vice-rei do Rio da Prata e de um ministro espanhol. ${ }^{68}$ De fato, o vice-rei Nicolás de Arredondo fez notar ao secretário de Índias que a cédula entrava em conflito com o convênio de restituiçáo incluso no Tratado de Santo Ildefonso. ${ }^{69}$ Tais reaçôes demonstram que a política do asilo já não encontrava apoio na Espanha e na América. Depois de 1791, autoridades espanholas voltaram ocasionalmente a alforriar fugitivos, mas quase sempre em tempos de guerra. A liberdade era concedida em troca do recrutamento ou para causar prejuízo aos inimigos. ${ }^{70}$

\section{Conclusão}

A política espanhola de conceder alforria a escravos fugidos de colônias estrangeiras persistiu por mais de um século e foi oficializada em cédulas reais emitidas de 1680 a 1789 . Sua emergência decorreu de uma prática espontânea que brotou quase simultaneamente em diferentes lugares do Caribe e na Flórida nas décadas de 1670 e 1680. Colonos e autoridades

\footnotetext{
${ }^{65}$ RUPERT, Linda M. 'Seeking the water of baptism': fugitive slaves and imperial jurisdiction in the early modern Caribbean, op. cit., p. 216.

66 "Convención entre España y Holanda para restituirse mutuamente los desertores y fugitivos de sus colonias americanas, Aranjuez, 23/06/1791”. In: CANTILLO, Alejando del. Tratados, convenios y declaraciones de paz y de comercio que han hecho con las potencias extranjeras los monarcas españoles de la Casa de Borbón, op. cit., p. 633-634.

${ }^{67}$ LANDERS, Jane. Spanish sanctuary: fugitives in Florida, 1687-1790, op. cit., p. 311-313.

${ }^{68}$ ALADRÉN, Gabriel. Sem respeitar fé nem tratados: escravidão e guerra na formação histórica da fronteira sul do Brasil (Rio Grande de São Pedro, c. 1777-1835), op. cit., p. 170-172.

69 "Carta de Nicolás Arredondo a Antonio Valdés, Buenos Aires, 10/05/1790". Archivo General de la Nación Argentina, Sala IX, División Colonia, Sección Gobierno, Correspondencia Loreto-Arredondo, 1788-1790, legajo 8-2-6.

${ }^{70}$ Foi o que aconteceu, por exemplo, na guerra hispano-portuguesa de 1801, no Rio da Prata, e na participação espanhola na Revolução de São Domingos. Cf. ALADRÉN, Gabriel. Sem respeitar fé nem tratados: escravidão e guerra na formação histórica da fronteira sul do Brasil (Rio Grande de São Pedro, c. 1777-1835), op. cit., 2012, p. 210-224; FERRER, Ada. Freedom's mirror: Cuba and Haiti in the age of revolution, op. cit., 2014, p. 83-145.
} 
locais começaram a alforriar africanos oriundos das possessóes francesas e inglesas, como parte de um conjunto de respostas débeis e erráticas à pressão provocada pela expansão dos impérios escravistas norte-europeus. Essas iniciativas foram articuladas pela diplomacia espanhola, onde adquiriram função e sentido globais. Além de retaliar e ameaçar os rivais, a incorporação dos fugitivos como súditos da Coroa promovia o povoamento e a defesa militar de áreas de fronteira do império espanhol.

Os alinhamentos da política internacional europeia ajudam a explicar a dinâmica da política de asilo. $\mathrm{O}$ ardil espanhol consistia em ameaçar com decretos de liberdade e, eventualmente, negociar convênios bilaterais de restituição. O direito de asilo era usado como instrumento diplomático de pressão e retaliação, principalmente em contextos de tensão e conflito com outros Estados. É evidente que seria completamente ineficaz se jamais fosse aplicado, mas as comunidades de negros libertos espalhadas pelos diversos quadrantes do império espanhol eram uma lembrança incômoda de que a ameaça poderia se tornar realidade, até porque os escravos utilizavam com inteligência as brechas dos regimes legais em seu benefício.

$\mathrm{Na}$ medida em que o asilo foi positivado em lei, recorreu-se a fontes do direito e a justificativas variadas para sua legitimação. As primeiras cédulas mencionavam castigos físicos excessivos e maus-tratos que proprietários estrangeiros dispensavam a seus escravos, mas logo o principal argumento passou a ser o suposto desejo dos fugitivos de receberem o batismo na Igreja Católica. Até a Guerra dos Sete Anos, tal justificativa pôde ser mantida e reforçada, pois a política do asilo era direcionada aos impérios cuja religiáo oficial era protestante. Depois, o pretexto do batismo foi abandonado e em seu lugar o direito de gentes e o apelo à humanidade dos escravos assumiram o protagonismo retórico. A transformação discursiva e a nova base legal e moral das cédulas se explicam porque elas passaram a ser utilizadas contra Portugal e França, duas naçóes católicas.

Ao mesmo tempo que a política de asilo se ancorou em justificativas puramente seculares e passou a mirar os escravos de qualquer império rival no Novo Mundo, ela começou a ser sistematicamente minada. Houve uma proliferação de tratados bilaterais da Espanha com naçôes estrangeiras determinando a restituição de fugitivos. $\mathrm{O}$ fortalecimento da escravidão na América espanhola comprometeu colonos, administradores e a Coroa com a defesa de sua segurança e legitimidade, inclusive no plano internacional. O golpe final foi desferido pelas revoluçôes francesa e haitiana, que provocaram nos senhores e nas autoridades o receio de que negros fugitivos portavam ideias subversivas.

Evidentemente, os escravos não deixaram de cruzar as fronteiras do império espanhol em busca da liberdade. Décadas de existência do fenômeno criaram rotas e circuitos de solidariedade que facilitavam o acolhimento dos fugitivos, bem como geraram uma memória do asilo, que embalava os sonhos de muitos homens e mulheres escravizados. $\mathrm{O}$ sucesso das fugas, como antes, não dependia unicamente da normativa legal e das diretrizes diplomá- 
ticas, mas sobretudo de condiçóes socioeconômicas e arranjos políticos regionais. Ainda assim, a política de asilo como regra geral e recurso diplomático da Coroa espanhola para tempos de paz deixou de existir. A prática de libertar escravos fugitivos voltou a apresentar, de certo modo, características semelhantes às que possuía quando surgiu: medidas pontuais, contingentes e dispersas, frequentemente vinculadas ao recrutamento e a alianças militares, adotadas como reaçóes locais e espontâneas aos desafios que a era das revoluções impôs aos colonos e às autoridades hispano-americanas.

Não se pode dizer, no entanto, que o asilo aos escravos fugitivos como instituição legal e prática político-militar tenha acabado. Na verdade, ele se reatualizaria num terreno ideológico, econômico e geopolítico transformado. Depois de ter sido instrumento diplomático de uma política global da monarquia espanhola, o direito de asilo criou jurisprudência e tradição legal duradoura. Não por acaso, no século XIX, ele seria rememorado por patriotas e revolucionários para justificar o princípio do solo livre. Se em Cuba, no Brasil e no Sul dos Estados Unidos o fortalecimento da escravidão aumentaria a preocupação com a segurança da instituição e o controle dos fugitivos, no Haiti e nas repúblicas hispano-americanas o solo livre foi fator constituinte dos Estados nacionais. No aparentemente paradoxal mundo atlântico oitocentista, onde a marcha célere da liberdade conviveu com o fortalecimento da escravidão, a antiga tradição espanhola do asilo a escravos fugitivos encontraria solo fértil para florescer.

\section{Referências bibliográficas}

ADELMAN, Jeremy. Sovereignty and revolution in the Iberian Atlantic. Princeton: Princeton University Press, 2006.

AIZPURÚA, Ramón. Esclavitud, navegación y fugas de esclavos en el Curazao del siglo XVIII. In: DALLA CORTE, Gabriela (Org.). Poder local, poder global en América Latina. Barcelona: UBe, 2008, p. 81-94.

ALADRÉN, Gabriel. Sem respeitar fé nem tratados: escravidão e guerra na formação histórica da fronteira sul do Brasil (Rio Grande de São Pedro, c. 1777-1835). Tese (doutorado em história) - Programa de Pós-Graduação em História, Universidade Federal Fluminense, Niterói, 2012.

ALDEN, Dauril. The undeclared war of 1773-1777: climax of Luso-Spanish Platine rivalry. The Hispanic American Historical Review, v. 41, n. 1, p. 55-74, 1961.

ALENCASTRO, Luiz Felipe de. O trato dos viventes: formação do Brasil no Atlântico Sul. Sáo Paulo: Companhia das Letras, 2000.

ALLAIN, Jean (Org.). The legal understanding of slavery: from the historical to the 
contemporary. Oxford: Oxford University Press, 2012.

ANDRÉS-GALLEGO, José. La esclavituden la monarquia hispánica: un estudio comparativo. Madri: Fundación Ignacio Larramendi/Fundación MAPFRE Tavera, 2005 [CD-ROM].

BERBEL, Márcia; MARQUESE, Rafael; PARRON, Tâmis. Escravidão e politica: Brasil e Cuba, 1790-1850. São Paulo: Hucitec, 2010.

BLACK, Jeremy. Trade, empire and British foreign policy, 1689-1815: the politics of a commercial state. Londres: Routledge, 2007.

BLACKBURN, Robin. A construção do escravismo no Novo Mundo: do barroco ao moderno, 1492-1800. Rio de Janeiro: Record, 2003.

. The American crucible: slavery, emancipation and human rights. Londres: Verso, 2011. CASTELNAU-L'ESTOILE, Charlotte de. Operários de uma vinha estéril: os jesuítas e a conversão dos índios no Brasil, 1580-1620. Bauru: Edusc, 2006.

DAVIES, Kenneth Gordon. The North Atlantic world in the seventeenth century. Mine'spolis: University of Minnesota Press, 1974.

DAVIS, David Brion. O problema da escravidão na cultura ocidental. Rio de Janeiro: Civilização Brasileira, 2001.

DEIVE, Carlos Esteban. Los guerrilleros negros: esclavos fugitivos y cimarrones en Santo Domingo. Santo Domingo: Fundación Cultural Dominicana, 1989.

DELGADO RIBAS, Josep M. Dinámicas imperiales (1650-1796). España, América y Europa en el cambio institucional del sistema colonial español. Barcelona: Bellaterra, 2007. ELLIOTT, John H. Empires of the Atlantic world: Britain and Spain in America, 1492-1830. New Haven: Yale University Press, 2006.

. Imperial Spain, 1469-1716. Londres: Penguin Books, 2002.

FERRER, Ada. Freedom's mirror: Cuba and Haiti in the age of revolution. Cambridge: Cambridge University Press, 2014.

GARAVAGLIA, Juan Carlos; MARCHENA, Juan. América Latina de los orígenes a la independencia. Barcelona: Crítica, 2005. v. 1.

GRADY, Timothy Paul. Anglo-Spanish rivalry in Colonial South-East America, 1650-1725. Londres: Pickering \& Chatto, 2010.

GRINBERG, Keila. Fronteiras, escravidão e liberdade no sul da América. In: GRINBERG, Keila (Org.). As fronteiras da escravidão e da liberdade no sul da América. Rio de Janeiro: 7Letras, 2013, p. 7-24.

Illegal Enslavement, International Relations, and International Law on the Southern Border of Brazil. Law and History Review, v. 35, n. 1, p. 31-52, 2017.

HALL, N. A. T. Maritime maroons: 'grand marronage' from the Danish West Indies. The 
William and Mary Quarterly, v. 42, n. 4, p. 476-498, out. 1985.

HEMMING, John. Red gold: the conquest of the Brazilian Indians. Cambridge: Harvard University Press, 1978.

HUNT, Lynn. A invenção dos direitos humanos: uma história. São Paulo: Companhia das Letras, 2009.

LANDERS, Jane. Gracia Real de Santa Teresa de Mose: a free black town in Spanish colonial Florida. The American Historical Review, v. 95, n. 1, p. 9-30, 1990.

. Spanish sanctuary: fugitives in Florida, 1687-1790. The Florida Historical Quarterly, v. 62, n. 3, p. 296-313, 1984.

LUCENA SALMORAL, Manuel. Leyes para esclavos: el ordenamiento jurídico sobre la condición, tratamiento, defensa y represión de los esclavos en las colonias de la América española. Madri: Fundación Histórica Tavera, 2000.

MARCOCCI, Giuseppe. Escravos ameríndios e negros africanos: uma história conectada: teorias e modelos de discriminação no império português (ca. 1450-1650). Tempo, v. 16, n. 30, p. 41-70, 2011.

MARQUESE, Rafael de Bivar. Feitores do corpo, missionários da mente. Senhores, letrados e o controle dos escravos nas Américas, 1660-1860. São Paulo: Companhia das Letras, 2004. MATTOS, Hebe. A escravidáo moderna nos quadros do Império português: o Antigo Regime em perspectiva atlântica. In: FRAGOSO, João; BICALHO, Maria Fernanda; GOUVÊA, Maria de Fátima (Orgs.). O Antigo Regime nos trópicos: a dinâmica imperial portuguesa (séculos XVI-XVIII). Rio de Janeiro: Civilização Brasileira, 2001, p. 141-162.

MENARD, Russell R. Slave demography in the Lowcountry, 1670-1740: from frontier society to plantation regime. The South Carolina Historical Magazine, v. 96, n. 4, p. 280303, 1995.

MORGAN, Kenneth. Anglo-Dutch economic relations in the Atlantic World, 1688-1783. In: KLOOSTER, Wim; ROITMAN, Jessica V. (Orgs.). Dutch Atlantic connections, 16801800: linking empires, bridging borders. Leiden: Brill, 2014, p. 119-138.

PAGDEN, Anthony. La caída del hombre natural: el indio americano y los orígenes de la etnología comparativa. Madri: Alianza Editorial, 1988.

PATTERSON, Orlando. Slavery and social death: a comparative study. Cambridge, MA: Harvard University Press, 1982.

PEARCE, Adrian J. The origins of Bourbon reform in Spanish South America, 1700-1763. Nova York: Palgrave Macmillan, 2014.

PETIT MUÑOZ, Eugenio et al. La condición jurídica, social, económica y politica de los negros durante el coloniaje en la Banda Oriental. Montevidéu: Facultad de Derecho y Ciencias Sociales, 1948.

PETITJEAN-ROGET Jacques. Les protestants à la Martinique sous l'ancien régime. Revue 
d'histoire des colonies, v. 42, n. 147, p. 220-265, 1955.

RUIZ IBÁÑEZ, José Javier; VINCENT, Bernard. Historia de España. Los siglos XVI-XVII: política y sociedad. Madri: Síntesis, 2007.

RUPERT, Linda M. 'Seeking the water of baptism': fugitive slaves and imperial jurisdiction in the early modern Caribbean. In: BENTON, Lauren; ROSS, Richard J. (Orgs.). Legal pluralism and empires, 1600-1850. Nova York: New York University Press, 2013, p. 199-231. SILVA, Cristina Nogueira da; GRINBERG, Keila. Soil free from slaves: slave law in the late eighteenth- and early nineteenth century Portugal. Slavery \& Abolition, v. 32, n. 3, p. 431446, 2011.

STEIN, Stanley J.; STEIN, Barbara Hadley. Silver, trade, and war: Spain and America in the making of early modern Europe. Baltimore: The Johns Hopkins University Press, 2000. TAU ANZOÁTEGUI, Víctor. Nuevos horizontes en el estudio histórico del derecho indiano. Buenos Aires: Instituto de Investigaciones de Historia del Derecho, 1997.

TEPASKE, John J. The fugitive slave: intercolonial rivalry and Spanish slave policy, 16871764. In: PROCTOR, Samuel (Org.). Eighteenth-century Florida and its borderlands. Gainesville: University of Florida Press, 1975, p. 1-12.

THOMPSON, Alvin O. Flight to freedom: African runaways and maroons in the Americas. Kingston: University of the West Indies Press, 2006.

WALKER, Geoffrey J. Spanish politics and imperial trade, 1700-1789. Londres: Macmillan, 1979.

WILLIAMS, Eric. Capitalism and slavery. Chapel Hill, NC: The University of North Carolina Press, 1944.

WRIGHT, Irene A. Dispatches of Spanish officials bearing on the free negro settlement of Gracia Real de Santa Teresa de Mose, Florida. The Journal of Negro History, v. 9, n. 2, p. 166-172, 1924.

ZERON, Carlos Alberto. Linha de fé: a Companhia de Jesus e a escravidão no processo de formação da sociedade colonial (Brasil, séculos XVI e XVII). São Paulo: Edusp, 2011.

\section{Como citar}

ALADRÉN, Gabriel. Bajo mi real protección y amparo: os decretos espanhóis de liberdade a escravos fugitivos e os conflitos imperiais no Atlântico, 1680-1791. Topoi. Revista de História, Rio de Janeiro, v. 18, n. 36, p. 514-536, set./dez. 2017. Disponível em: <www. revistatopoi.org>. 